\title{
Contaminants Leaching from Fresh Poultry Waste: A Lysimeter Study on Sandy Soils under Tropical Conditions
}

\author{
Peter Aderemi Adeoye ${ }^{1}$, Hasfalina Che Man ${ }^{1}$, Mohd. Amin Soom ${ }^{1}$, Ahmad Mohammed Thamer ${ }^{2}$ \& Akinbile \\ Christopher Oluwakunmi ${ }^{3}$ \\ ${ }^{1}$ Department of Biological and Agricultural Engineering, University Putra, Darul Ehsan, Selangor, Malaysia \\ ${ }^{2}$ Department of Civil Engineering, University Putra, Darul Ehsan, Selangor, Malaysia. \\ ${ }^{3}$ Department of Agricultural and Environmental Engineering, Federal University of Technology, Akure, Nigeria \\ Correspondence: Peter Aderemi Adeoye, Department of Biological and Agricultural Engineering, University \\ Putra, Darul Ehsan, Selangor, Malaysia. E-mail: pheterhardey@yahoo.com
}

Received: July 7, $2014 \quad$ Accepted: September 10,2014 Online Published: March 31, 2017
doi:10.5539/ep.v6n1p38
URL: https://doi.org/10.5539/ep.v6n1p38

\begin{abstract}
A lysimeter study was conducted on sandy soil of Minna, North central Nigeria to assess the migration of nitrates, phosphates, bacteriological parameters and heavy metals contents of poultry manure through Minna soil. This is with a view to examining the environmental effect of indiscriminate land application of excessive poultry manure on shallow groundwater quality. A lysimeter and rainfall simulator assembly was installed on an undisturbed $0.9 \mathrm{~m}$ diameter, $3 \mathrm{~m}$ depth soil core after which $50 \mathrm{~kg}$ of characterized poultry manure was applied at the top. Rainfall of $125 \mathrm{~mm}$ was simulated and water samples were collected at different depths of the soil core through the lysimeter and were taken to laboratory for analysis. Results showed that nitrate and phosphate in poultry manure were able to leach to a depth of $2.5 \mathrm{~m}$ of the soil core four months after poultry manure application while turbidity and electrical conductivity reached their maximum value at depth $2.5 \mathrm{~m}$ after three months. Faecal coliform, total coliform and faecal streptococci were detected at depth $2.5 \mathrm{~m}$ also two months after the application. Statistical analysis using New Duncan Multiple Range test showed significant variation $(\mathrm{p}<0.05)$ of all the parameters tested with depth of sample collection and months after application of poultry manure. Spearman's correlation coefficient established both positive and negative correlation between the parameters studied in this research. Heavy metals tested, Arsenic, copper, zinc, chromium and manganese were not able to leach beyond $0.5 \mathrm{~m}$ depth of the soil core throughout the experimental period.
\end{abstract}

Keywords: aquifer vulnerability, lysimeter, poultry manure, heavy metals

\section{Introduction}

Site of application of manure plays a major role in controlling the mobility of contaminants through soil to groundwater as site variables that control compound mobility in the hydrosphere like soil, hydrogeological conditions, land use systems and climate differ from one location to another. This may be as a result of different soil and hydrogeological settings offering different vulnerability and different degrees of protection to the underlying aquifer (Collin and Melloul, 2003). A variety of mathematical and numerical models has been used to assess the vulnerability of shallow aquifer by estimating time of arrival of pollutants percolating through the vadose zone from the ground surface to the water table. However, the estimation does not always represent reality. It can result from incorrect assumption made with dynamics of pollutant transport and groundwater flow. Therefore, the understanding of water movement through porous media is important to guard against mobility of residual chemicals, manure and other polluting compounds to the groundwater from anthropogenic activities (Gehl et al., 2005).

Vulnerability and leaching are considered to be site specific, depth to water table, soil hydraulic properties and groundwater recharge conditions determine the fate and persistence of any contaminants in the subsurface. Migration of contaminants from polluting sources into shallow groundwater has been reported by researchers the world over (Lerner and Harris, 2009). However, the concept has not been given needed attention in some developing nations and as a result, shallow wells and deep boreholes are still sited close to septic tanks and animal waste dump sites. While deep boreholes may not be affected by these polluting sources because of the 
depth, attenuation power of the overlying soil and long contact time between soil and percolating water, (Kulabako et al.,2007) shallow wells are very susceptible to contamination from these sources if they are located close to the water hole.

Use of lysimeter to study migration of contaminants to groundwater has been recognized for many years because it has been of major importance in the development of understanding of soil water and contaminants dynamics in the subsurface. Earliest lysimeter consisted of a container filled with soil repacked to a similar bulk density of that in the fields. Ehler and Goss, (2003) and Goss et al. (2010) developed a non-weighing drainage lysimeter, tension lysimeter was developed by Gee et al. (2009) by placing a wick in contact with the soil body to carry water down into the collecting vessel. Goss and Ehlers (2009) developed a hybrid weighing lysimeter which allows the contaminant load entering unconfined shallow groundwater to be identified. Large weighing rigid-cased monolith lysimeter was used by Bergstron and Kirchmann (2004) to determine contaminant load moving below the rooting zone. Kartikeyan et al. (2008) studied the migration of faecal matter through soil with a drainage non-weighing lysimeter and the results shows fast movement of these bacteria as a result of very permeable nature of the vadose zone soil.

Poultry industry is a fast growing agro-based industry in the world today. The reason may be attributed to population increase and rising demand for poultry meat and egg product probably because of poultry meat low cholesterol content (Bolan et al., 2010). Though, these farms produce meat and egg products and also generate employment, however, one of the problems confronting the industry is the accumulation of waste which may pose pollution problems unless it is managed in an environmental friendly manner. Poultry waste contains high moisture content and other organic materials, which can create environmental problem as fly breeding, odour nuisance and greenhouse gas emission if it is not disposed of or managed appropriately (Coufal et al., 2006). In Nigeria, like any developing nation, there is a rapid expansion of small and medium scale poultry farms with the attendant effect of huge waste generation. The magnitude of this generated poultry waste has given rise to improper disposal which include over application to land, improper timing of application thereby creating pollution problem to soil and groundwater environment.

Minna, a town in North central area of Nigeria is not an exception to revolution poultry farms emergence and poor poultry waste management systems. The management pattern in Minna is characterized by a low level of specialization. Most of the huge amount of poultry waste produced in Minna is either applied excessively to agricultural land or flushed into water courses thereby creating serious pollution of eutrophication and oxygen depletion for aquatic animal. This process is also known to be capable of causing groundwater pollution by nitrates, phosphates, heavy metal and pathogenic organisms (Worrall et al., 2002). Leachates from the poultry waste have high concentration of organic as well as inorganic pollutants, composition of which exhibits spatial and temporal variations depending on site, management practices, waste characteristics and climate.

Many groundwater quality assessments have been carried out in Minna and the shallow aquifer of Minna has been discovered to be vulnerable to pollution from agricultural, domestic and industrial wastes (Adeoye et al., 2012). This was attributed to high permeability of the top soil which offers little protection to underlying aquifer. Shekwolo and Brisbe, reported poor bacteriological quality of groundwater close to domestic and industrial waste dumps in Niger State. Also Jimoh et al. (2003) found high concentration of electrical conductivity (EC) and total dissolved solids in shallow groundwater in Minna peri-urban environments and the concentration was attributed to various industrial effluents and concentration of abattoir activities in the area. Salami et al. (2008) attributed high concentration of lead, arsenic, and chromium in Minna shallow groundwater to contamination from petrol chemical industries which directly release their effluents to soil without ant treatment measure.

Reports of different cases of water borne diseases have been documented in Minna over the years Chukwu et al.(2004) reported nine years water borne diseases in Minna and also reported that major water borne diseases affecting Minna inhabitants are typhoid, diarrhea, cholera, amoebiasis and blue baby. It was concluded form his study that majority of people affected by these diseases are people living in the suburb and close to area where there are intensive farming activities like dairy, slaughters house and poultry activities. Some groundwater sampling campaign in North central Nigeria and Minna (Jimoh et al., 2003; Salami et al., 2008; Isikwue et al., 2011) have reported presence of nitrates, phosphates and biological parameters especially inside the poultry farms as a result of indiscriminate dumping of poultry manure. However, a mechanism guiding the transport of the pollutants through the vadose zone into the groundwater has not been adequately studied. There is therefore a need to ascertain behaviour of poultry manure contaminants through the soil profile to be able to predict and explain danger posed to groundwater aquifers by continuous and excessive application of poultry manure to agricultural lands. The objective of this work is therefore to conduct a lysimeter study on mobility of poultry waste organic and inorganic contaminants through the profile of Minna soil with a view to recommending 
adequate mitigation measures against shallow groundwater contamination by indiscriminate application of poultry manure.

\section{Materials and Methods}

\subsection{Description of the Study Site}

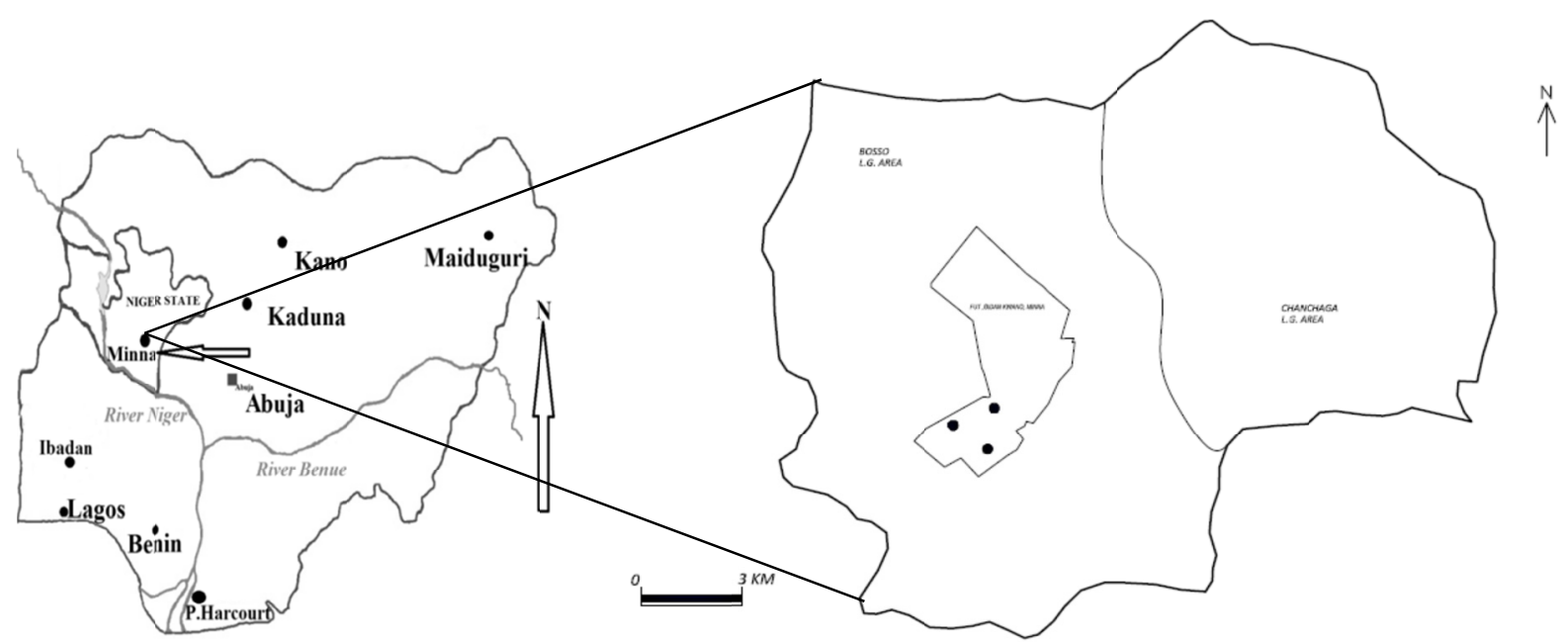

Figure 1. Map of Nigeria Showing Minna and Map of Minna Showing Study Location

The study area for this research is Minna, capital of Niger State, a semi - arid town in North central Nigeria, Figures 1 . The city lies in latitude $9^{0} 36^{\prime} 50^{\prime \prime} \mathrm{N}$ and longitude $6^{0} 33^{\prime} 25^{\prime}$. The population of Minna as at 2012 was 613,246 (NPC, 2012). River Chinchaga is the major river in Minna which drains into River Kaduna at about $45 \mathrm{~km}$ in the Northwestern side. Geology of Minna belongs to central portion of Nigerian basement complex rock of Precambrian in age though some of them are found in the early Paleozoic. The rock have been grouped into four lithological unit by Shekwolo and Brisbe, (1999) as gneiss-quartzite complex, schist belts, granitoids and metamorphosed basic rocks. Aquifers in Minna are either confined, semi-confined or unconfined. The unconfined aquifer has generally a shallow water table of about 20 meters though, there are perched conditions in some places and Minna aquifer is primarily recharged by rainfall. Adesiji and Jimoh, (2012). The major source of groundwater supply in Minna is shallow open wells (depth usually less than $10 \mathrm{~m}$ ) because of their high yield and relatively cheaper construction. The average static water level in Minna has been found to be $5.86 \mathrm{~m}$ and climatic conditions in Minna are presented in table 1.

Table 1. Climatic and Aquifer Conditions in Minna

\begin{tabular}{ccc}
\hline Climatic Factors & Minimum & maximum \\
\hline Annual Precipitation & $1100 \mathrm{~mm}$ & $1300 \mathrm{~mm}$ \\
Daily Sunshine Hours & 6.4 & 9.2 \\
Average temperature & $19^{0} \mathrm{C}$ & $40^{0} \mathrm{C}$ \\
Evapotranspiration & $25 \mathrm{~mm}$ & $90 \mathrm{~mm}$ \\
Aquifer Permeability & $0.44 \mathrm{~m} /$ day & $0.6 \mathrm{~m} /$ day \\
Aquifer Transmissivity & $55 \mathrm{~m}^{2} /$ day & $185 \mathrm{~m}^{2} /$ day \\
Storage coefficient & $2.6 \times 10^{-3}$ & $4.4 \times 10^{-3}$ \\
\hline
\end{tabular}

Source: Adesiji and Jimoh, 2012.

Three experimental plots measuring $15 \mathrm{~m}$ by $30 \mathrm{~m}$ each were selected for this experiment. The sites were located inside the research farm of Federal University of Technology Minna. (Figure 1). The marking out was done and topographical survey of the experimental site was done with Total Station (Leica TPS 1100) fitted with data collector (TDS-HP 48GX) and the prism pole. Geophysical survey was done to get the Schlumberger array then followed by Vertical Electric Sounding (VES) using Terrameter (ABEM SAS4000) and its accessories. Five 
geo-electric soundings were carried out on each of the plots using Schlumberger electrode array with maximum half current electrode spacing $(\mathrm{AB} / 2)$ of $6 \mathrm{~m}$ which was sufficient to allow a penetration depth of between 10-25m, typical of Minna shallow aquifer.

\subsection{Soil Excavation}

An undisturbed cylindrical soil core of $0.95 \mathrm{~m}$ diameter and $4 \mathrm{~m}$ depth was isolated on each of the plots. This was done by using the service local diggers. Flat steel sheet of gauge $16 \mathrm{~mm}$ was used to fabricate a $1 \mathrm{~m}$ diameter and $3.5 \mathrm{~m}$ long cylindrical lysimeter bin. The flat sheet metals were folded and edge were fitted with PVC rubber to make it water tight and then joined together with $17 \mathrm{~mm}$ bolts and nuts. Three holes each of 0.02 meter were drilled at $0.5 \mathrm{~m}$ length from the top and another three holes of the same size were drilled progressively at intervals of $0.5 \mathrm{~m}$ up to the $3 \mathrm{~m}$ length of the bin. Steel rod of $0.02 \mathrm{~m}$ diameter and $0.03 \mathrm{~m}$ long was welded on the hole and hose pipe (nestler tube) was fitted to the pipe to serve as water collector. At the other end of the hose, sterilized plastic bottle were fitted tightly to serve as water collector during the experimental runs. The function of the cylindrical lysimeter was to support the excavated undisturbed soil core and to also serve as a medium through which water would be collected from the soil. This was followed by aplication of 50kg poultry manure on the top of the soil core with $0.5 \mathrm{~m}$ length of lysimeter bin acting as side support for the applied poultry manure (Figure 2). A portable rainfall simulator was fabricated with $50.8 \mathrm{~mm}$ reducing diameter pipes to maintain a good pressure that will give the simulated raindrop a good impact to infiltrate the soil. The rainfall simulator also consist of one 1000liters PVC tank, one 5000litre/min centrifugal pump (GX120 4HP), 4 showers roses and pipe. These were coupled together to be used on the lysimeter assembly to augment natural rainfall.

\subsection{Experimental Runs and Water Sample Collection}

The complete experimental set up after installation is as shown in figure 2. Before the action of rainfall simulator and the application of poultry manure, soil samples were taken at depth $1 \mathrm{~m}, 2 \mathrm{~m}$ and $3 \mathrm{~m}$ of the soil core to serve as control. Rainfall of intensity $6.671 / \mathrm{min}$ was simulated on the lysimeter The pump was regulated so that 100litres of water fall on lysimeter of $1 \mathrm{~m}$ diameter (Area of $0.7855 \mathrm{~m}^{2}$ ) in fifteen minutes. The rainfall intensity translates into $125 \mathrm{~mm}$ of rainfall based on FAO, (1986) conversion factor. (1litre $/ \mathrm{m}^{2}=1 \mathrm{~mm}$ of rainfall). Water samples were collected from the attached sterilized can and the soil and water samples were taken to laboratory and analyzed to serve as initial properties of the soil and water on the experimental plots. The poultry manure was then applied and rainfall simulation begins. Soil and water samples were taken from the set up for six months at 1 month interval. The collected samples were taken to laboratory for analysis. 


\subsection{Water Samples Analysis}

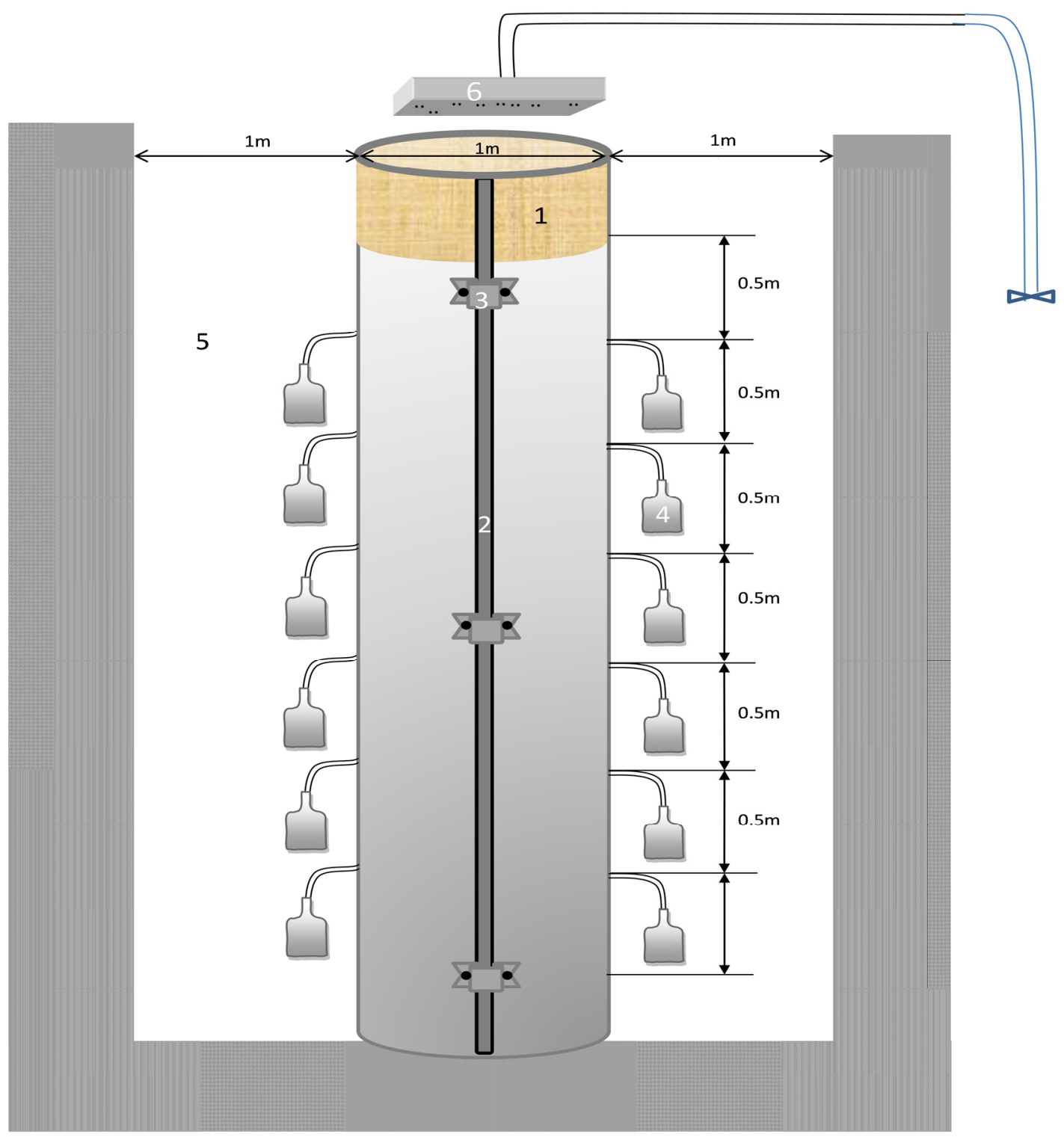

Figure 2. The Pictorial View of the Rainfall Simulator and Lysimeter Assembly

Legend: 1- Space where 50kg of poultry waste is applied. 2- The PVC rubber, 3- 17mm bolt and nuts, 4- The sterilised Plastic can for water collection, 5 - The space where soil is excavated, 6 - The rainfall simulator.

Physical parameters of the water samples were determined on-site temperature and $\mathrm{pH}$ were determined using $\mathrm{pH} /$ temperature meter (Ohaus S2000) while the Total Dissolved Solid (TDS), electrical conductivity (EC) and turbidity were determined with Jenway M470 portable conductivity/ TDS meter (Jemway M470). Samples for chemical and bacteriological analysis were stored under ice pack and taken to laboratory.

\subsection{Analysis for Chemical and Bacteriological Parameters}

Colorimeter method was used to determine the chemical parameters present in the waste sample. The equipment used was colorimeter (Hach DR 4000). For nitrate test, $10 \mathrm{ml}$ of the water sample was put inside a test tube, and 1 sachet of NitraVer 5 reagent pillow was added. The mixture was agitated for 1 minute and allowed a reaction time of 5 minutes after which the nitrate concentration in the water sample was read from the colorimeter. This method was used for all the tested chemical parameters except manganese and Arsenic, though the reagent pillows and reaction times differ. The reagent pillow, reaction time, program number and analysis name for all the chemical parameters are as contained in Hach Data logging Colorimeter Procedure Manual, (2000). Presence 
of manganese in the water samples was determined by periodate oxidation (Choo et al., 2005) method while arsenic was determined by Nickson et al. (2000) method. Membrane filtration Technique reported by Howard et al. (2003) was used to determine the presence of bacteriological parameters. Results obtained were subjected to analysis of variance to determine if the water samples properties change with date of collection and to ascertain if the depth, from which the samples were taken have any effect on water properties. Interaction between time of poultry waste application on the undisturbed soil core and the depth at which the water samples were collected was also determined. The mean obtained were also subjected to Duncan Multiple Range Test.

\section{Results and Discussions}

\subsection{Migration of Chemical Parameters}

Chemical parameters values obtained varied both with depths and the months after application of poultry waste on the lysimeter. For instance, the smallest of all the chemical parameters were recorded from the water samples collected before the application of poultry waste though nitrate values were higher at depths $1.5 \mathrm{~m}$ and $2.0 \mathrm{~m}$. This may be due to presence of soil residual nitrogen from farming activities and manure introduced by grazing animals. However, after the introduction of $50 \mathrm{~kg}$ poultry manure on the lysimeter and rainfall simulation, chemical parameters of the water samples collected from the soil core witnessed sharp increase at depths $0.5 \mathrm{~m}$ to depth $1.5 \mathrm{~m}$. Highest nitrates and phosphates values were recorded at depths 1.0 one and two months after poultry waste introduction. Similarly, highest nitrates and phosphates values were obtained at depths $1.0 \mathrm{~m}, 1.5 \mathrm{~m}$ and 2.0 meters but the values started declining 5 months after waste introduction as shown in figures 3 and 4 . Values recorded for nitrates and phosphates at depths $2.5 \mathrm{~m}$ and $3.0 \mathrm{~m}$ depths were very small and show slight deviation from values obtained at depth $0.5 \mathrm{~m}$ before application of poultry waste. This may be an indication that nitrates and phosphates content of the introduced waste was unable to leach up to a depth of $2.5 \mathrm{~m}$ of the soil within the period of the experiment.

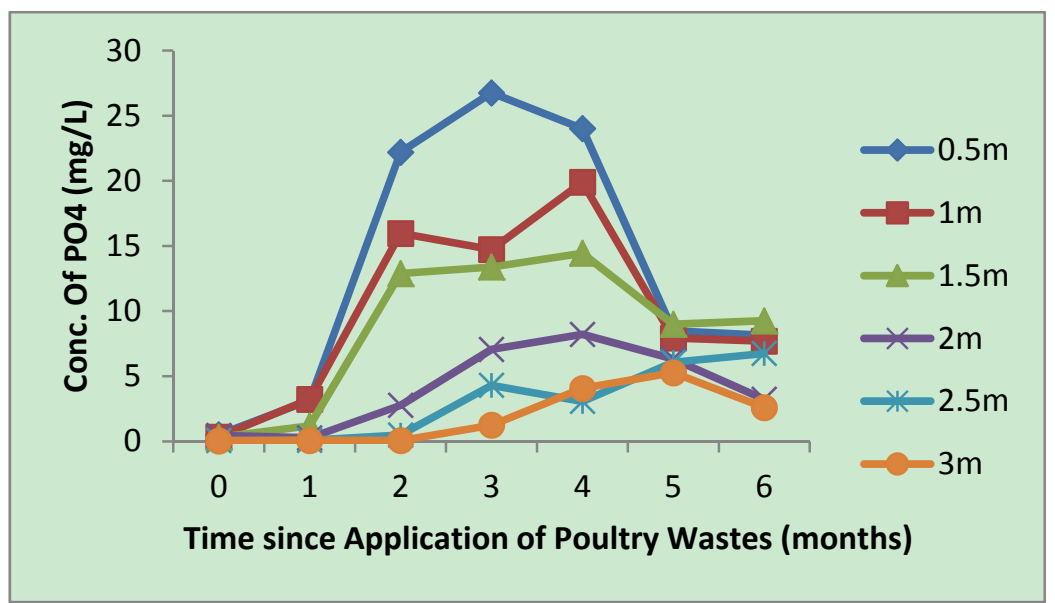

Figure 3. Concentration of $\mathrm{PO}_{4}$ at Various Depths of the Soil Core

As shown in table 2 , significant difference $(\mathrm{p}<0.05)$ were recorded between values of phosphates and nitrates both at different depths and with different time of waste application. From the table for instance, significant difference was only recorded between phosphates values at $0.5 \mathrm{~m}$ and other depths but no significant difference exist between phosphates vales obtained for other depths. This probably confirms the slow mobility of phosphates in the subsurface as reported by Kartikeyan et al. (2008). However, from the table, significant difference was recorded for nitrate values at different depths of the lysimeter except at depths $2.5 \mathrm{~m}$ and $3.0 \mathrm{~m}$ where no significant difference exist $(\mathrm{p}<0.05)$. 


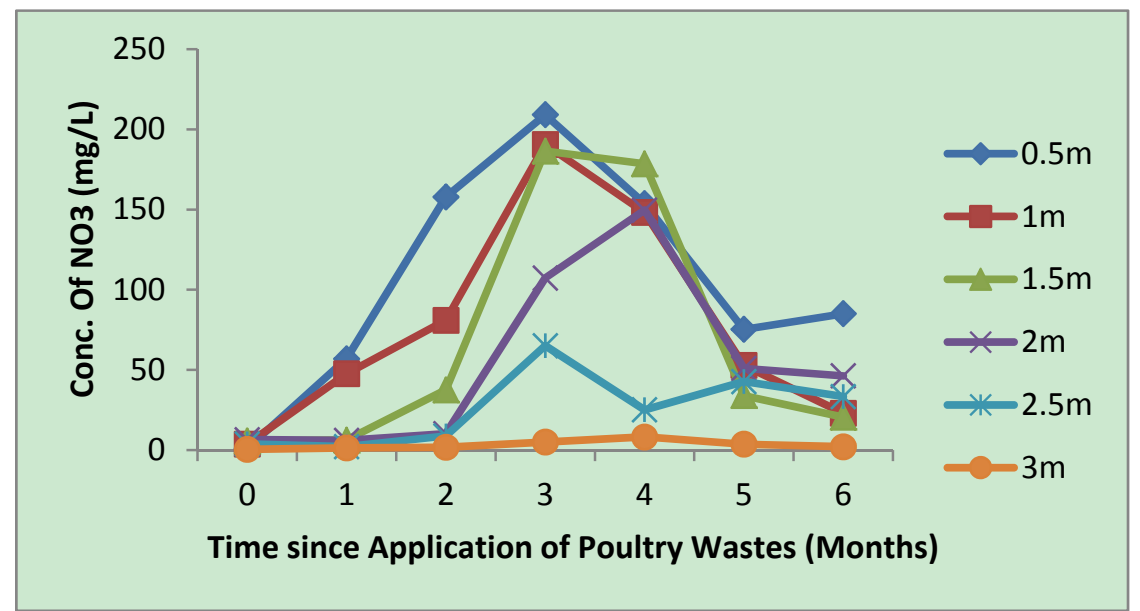

Figure 4. Concentration of $\mathrm{NO}_{3}$ at Various Depths of the Soil Core

Table 2. Comparison of Mean of Chemical Parameters Using NDMR Test

\begin{tabular}{|c|c|c|c|c|c|c|}
\hline Factors & & $\mathrm{PO}_{4}^{-3}$ & $\mathrm{NO}_{2}^{-}$ & $\mathrm{NO}_{3}^{-}$ & $\mathrm{NO}_{3}-\mathrm{N}$ & $\mathrm{NH}_{4}-\mathrm{N}$ \\
\hline \multirow{6}{*}{ Depth (m) } & 0.5 & $14.76^{\mathrm{a}}$ & $8.63^{\mathrm{a}}$ & $129.32^{\mathrm{a}}$ & $63.04^{\mathrm{a}}$ & $85.80^{\mathrm{a}}$ \\
\hline & 1.0 & $9.97^{\mathrm{b}}$ & $9.52^{\mathrm{a}}$ & $104.28^{\mathrm{b}}$ & $62.62^{\mathrm{a}}$ & $50.62^{\mathrm{b}}$ \\
\hline & 1.5 & $8.64^{\mathrm{b}}$ & $10.68^{\mathrm{a}}$ & $84.54^{\mathrm{c}}$ & $49.58^{\mathrm{b}}$ & $39.38^{\mathrm{c}}$ \\
\hline & 2.0 & $7.19^{\mathrm{b}}$ & $7.02^{\mathrm{b}}$ & $59.56^{\mathrm{d}}$ & $43.16^{\mathrm{b}}$ & $43.09^{b}$ \\
\hline & 2.5 & $7.26^{\mathrm{b}}$ & $5.43^{\mathrm{c}}$ & $45.00^{\mathrm{e}}$ & $40.84^{\mathrm{b}}$ & $29.68^{c}$ \\
\hline & 3.0 & $7.22^{\mathrm{b}}$ & $4.23^{\mathrm{c}}$ & $34.56^{\mathrm{e}}$ & $36.35^{\mathrm{b}}$ & $16.54^{\mathrm{d}}$ \\
\hline \multirow{7}{*}{ Time since Application (month) } & before & $0.33^{\mathrm{a}}$ & $0.30^{\mathrm{a}}$ & $5.57^{\mathrm{a}}$ & $3.47^{\mathrm{a}}$ & $0.58^{\mathrm{a}}$ \\
\hline & 1 & $1.33^{\mathrm{a}}$ & $1.47^{\mathrm{a}}$ & $20.02^{\mathrm{b}}$ & $15.50^{\mathrm{b}}$ & $4.71^{\mathrm{b}}$ \\
\hline & 2 & $9.06^{\mathrm{b}}$ & $7.74^{\mathrm{b}}$ & $91.72^{\mathrm{c}}$ & $43.46^{\mathrm{c}}$ & $15.08^{\mathrm{c}}$ \\
\hline & 3 & $12.91^{\mathrm{c}}$ & $10.64^{\mathrm{c}}$ & $148.29^{\mathrm{d}}$ & $81.40^{\mathrm{d}}$ & $11.00^{\mathrm{d}}$ \\
\hline & 4 & $15.95^{\mathrm{c}}$ & $12.38^{\mathrm{c}}$ & $135.56^{\mathrm{d}}$ & $66.31^{\mathrm{d}}$ & $18.65^{\mathrm{e}}$ \\
\hline & 5 & $12.04^{\mathrm{b}}$ & $7.99^{\mathrm{b}}$ & $51.78^{\mathrm{e}}$ & $70.30^{\mathrm{d}}$ & $18.62^{\mathrm{e}}$ \\
\hline & 6 & $11.28^{\mathrm{b}}$ & $11.72^{\mathrm{c}}$ & $75.37^{\mathrm{f}}$ & $56.98^{\mathrm{c}}$ & $20.28^{\mathrm{e}}$ \\
\hline
\end{tabular}

Values on the same columns with the same superscript are not significantly difference $(p<0.05)$ while values with different superscript are significantly different at $p<0.05$. NDMR-New Duncan Multiple Range Test.

High mobility of nitrates in the subsurface has been reported (Nyenje et al., 2013) and from this experimental set up, nitrate compounds were able to migrate to a depth of $2 \mathrm{~m}$ within 6 months of poultry waste application.

Significant variations were also observed between phosphate and nitrate values obtained at different months after application of poultry waste to the lysimeter. As shown in table 2, significant variation exists at nitrates values obtained at different months except between fourth and fifth months. This may probably confirm the fact that the soil in the experimental plot has very low attenuation capacity towards nitrate possibly because of high hydraulic conductivity. Migration of $\mathrm{PO}_{4}$ and $\mathrm{NO}_{3}$ (major chemical contaminants in poultry manure) from the surface to a depth of $2.5 \mathrm{~m}$ only took place within six months of waste introduction.

Lowest values were recorded for both phosphate and nitrate before poultry waste introduction ( 0 Month) and the highest values recorded for $\mathrm{NO}_{3}$ at depths $0.5,1.0,1.5$ and $2.5 \mathrm{~m}$ three months after application of poultry waste while the values was highest at $2 \mathrm{~m}$ depth four months after application of poultry waste. For $\mathrm{PO}_{4}$, highest values were recorded at $0.5,1.0,1.5,2.0$ and $2.5 \mathrm{~m}$ after four months as shown in figures 3 and 4 . These observations 
clearly point to the fact that unlined shallow wells of depth $2.5 \mathrm{~m}$ in Minna stands the risk of contamination by $\mathrm{PO}_{4}$ and $\mathrm{NO}_{3}$ within four months of locating poultry dumps close to the wells especially within a distance not up to safe lateral distance.

\subsection{Migration of Physical Parameters}

The physical parameters which are indications of contaminants within the soil profile vary with depths from which water samples were collected from the soil core and also on monthly basis. Though there is no significant variation in the $\mathrm{pH}$ and temperature vales of the water samples with depths and time after which the poultry waste was applied. However, other physical parameters change with these two variables. For instance, turbidity values were very less before application of the poultry waste but one month after the application, in all the depths where water samples were collected, turbidity values increased and the increment continued till five months after application of poultry waste (Figures 5 and 6 ).

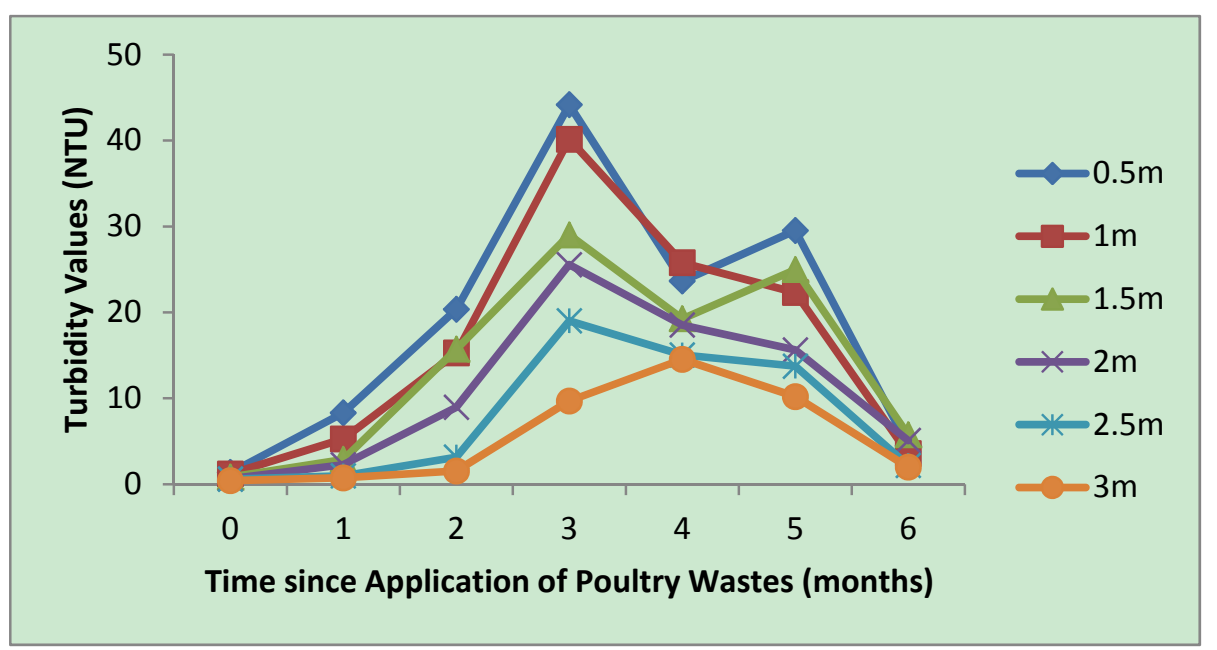

Figure 5. Concentration of Turbidity at Various Depths of the Soil Core

From the figures, Turbidity and EC values were least before application of the waste but increased to the highest value for all depths at 3 months after except for $3 \mathrm{~m}$ depth which reached its own highest value 4 months after. EC values were fat higher at $0.5 \mathrm{~m}$ depth than any other depths but also reached the maximum value 3 months after waste introduction. Electrical conductivity (EC) of the water samples also followed the same trend except at sixth month where the EC value was even higher than what obtained before poultry waste application especially at depths $0.5 \mathrm{~m}$ to $2.5 \mathrm{~m}$. Electrical conductivity has been explained (Nkandawire, 2008) as an indication of dissolved elements (metallic and non-metallic) in water and the increase in values may be attributed to the fact that infiltrating rain that was simulated on the soil core and applied poultry waste might have dissolved some organic and inorganic constituent of poultry was which are capable of raising EC values of the water samples. This may point to the fact that the sandy soil grain of the experimental plots might have filtered some particles as they travel through the soil core. 


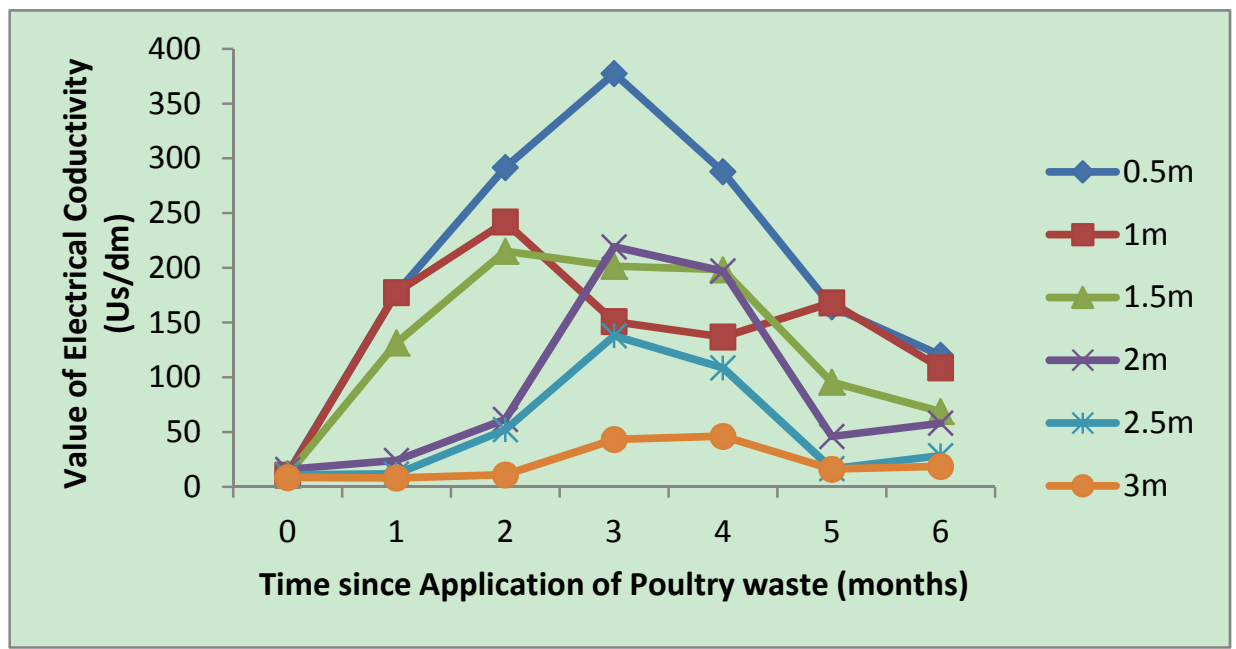

Figure 6. Concentration of Electrical Conductivity at Various Depths of the Soil Core

Statistically, as shown in table 3 , Though from the table, no significant difference was observed $(\mathrm{p}<0.05)$ between turbidity values from depth $0.5 \mathrm{~m}$ to $1.5 \mathrm{~m}$, significant variation was recorded at depths $2.0 \mathrm{~m}$ and $2.5 \mathrm{~m}$. Also, the turbidity values at $3.0 \mathrm{~m}$ were significantly difference from values obtained in all other depths (table 3 ). Depths also have statistically significant effects on EC of the water from $0.5 \mathrm{~m}$ to $1.0 \mathrm{~m}$, from $1.0 \mathrm{~m}$ to $1.5 \mathrm{~m}$ up to $3.0 \mathrm{~m}$. The same trend was also obtained for TDS except that no significant effect $(\mathrm{p}<0.05)$ was observed at depths 0.5 and $1.0 \mathrm{~m}$ and between 2.0 and $2.5 \mathrm{~m}$. Time since application of poultry waste is also important as shown in the table; it has remarkable effect on turbidity, EC and TDS values. What may be concluded from the variation in these physical parameters obtained from this experiment is that the contaminants that affect turbidity and EC of water in poultry waste can leach up to $2.5 \mathrm{~m}$ depth of Minna soil within three months after poultry waste dumping. In effect, continuous dumping over time will certainly increase the buildup of these contaminants and eventual serious contamination of the shallow aquifer.

Table 3. Comparison of Mean of Physical and Bacteriological Parameters Using NDMR Test

\begin{tabular}{|c|c|c|c|c|c|c|c|}
\hline Factors & & Turbidity & $\begin{array}{l}\text { Elect. } \\
\text { Cond. }\end{array}$ & $\begin{array}{l}\text { Total Diss. } \\
\text { Sol. }\end{array}$ & $\begin{array}{c}\text { Faecal } \\
\text { Coliform }\end{array}$ & $\begin{array}{c}\text { Total } \\
\text { Coliform }\end{array}$ & $\begin{array}{c}\text { Faecal } \\
\text { Streptococci }\end{array}$ \\
\hline \multirow{6}{*}{ Depth (m) } & 0.5 & $38.83^{\mathrm{a}}$ & $247.24^{\mathrm{a}}$ & $635.76^{\mathrm{a}}$ & $291.85^{\mathrm{a}}$ & $367.49^{\mathrm{a}}$ & $85.80^{\mathrm{a}}$ \\
\hline & 1.0 & $32.05^{\mathrm{a}}$ & $227.80^{\mathrm{b}}$ & $549.29^{\mathrm{a}}$ & $257.34^{\mathrm{b}}$ & $282.31^{\mathrm{b}}$ & $50.62^{\mathrm{b}}$ \\
\hline & 1.5 & $28.36^{\mathrm{a}}$ & $160.22^{\mathrm{c}}$ & $430.41^{\mathrm{b}}$ & $186.72^{\mathrm{c}}$ & $213.69^{c}$ & $39.38^{\mathrm{c}}$ \\
\hline & 2.0 & $19.44^{\mathrm{b}}$ & $117.35^{\mathrm{d}}$ & $259.81^{\mathrm{c}}$ & $120.29^{d}$ & $145.05^{\mathrm{d}}$ & $43.09^{b}$ \\
\hline & 2.5 & $13.60^{\mathrm{b}}$ & $84.56^{\mathrm{d}}$ & $207.29^{c}$ & $61.88^{\mathrm{e}}$ & $90.25^{\mathrm{e}}$ & $29.68^{c}$ \\
\hline & 3.0 & $9.87^{\mathrm{c}}$ & $42.95^{\mathrm{e}}$ & $150.25^{\mathrm{d}}$ & $33.24^{\mathrm{e}}$ & $58.25^{\mathrm{e}}$ & $16.54^{\mathrm{d}}$ \\
\hline \multirow{7}{*}{$\begin{array}{l}\text { Time since } \\
\text { Application } \\
\text { (month) }\end{array}$} & before & $0.83^{\mathrm{a}}$ & $11.45^{\mathrm{a}}$ & $25.75^{\mathrm{a}}$ & $3.30^{\mathrm{a}}$ & $4.73^{\mathrm{a}}$ & $0.45^{\mathrm{a}}$ \\
\hline & 1 & $3.40^{\mathrm{a}}$ & $88.31^{\mathrm{b}}$ & $216.68^{\mathrm{b}}$ & $116.89^{b}$ & $170.88^{\mathrm{b}}$ & $22.11^{\mathrm{b}}$ \\
\hline & 2 & $25.83^{b}$ & $145.56^{\mathrm{c}}$ & $375.68^{c}$ & $152.15^{\mathrm{b}}$ & $192.09^{c}$ & $36.81^{\mathrm{c}}$ \\
\hline & 3 & $38.09^{c}$ & $221.68^{\mathrm{d}}$ & $661.41^{\mathrm{d}}$ & $217.74^{\mathrm{c}}$ & $267.41^{\mathrm{d}}$ & $49.24^{\mathrm{d}}$ \\
\hline & 4 & $42.80^{\mathrm{c}}$ & $262.40^{\mathrm{d}}$ & $701.48^{\mathrm{d}}$ & $343.89^{c}$ & $353.84^{\mathrm{d}}$ & $95.04^{\mathrm{e}}$ \\
\hline & 5 & $51.06^{\mathrm{d}}$ & $226.00^{\mathrm{d}}$ & $603.61^{\mathrm{d}}$ & $126.85^{\mathrm{b}}$ & $169.06^{\mathrm{b}}$ & $61.47^{\mathrm{d}}$ \\
\hline & 6 & $3.84^{\mathrm{a}}$ & $71.40^{\mathrm{b}}$ & $20.35^{\mathrm{a}}$ & $149.03^{b}$ & $191.87^{\mathrm{c}}$ & $44.18^{\mathrm{c}}$ \\
\hline
\end{tabular}

Values on the same columns with the same superscript are not significantly difference $(p<0.05)$ while values with different superscript are significantly different at $p<0.05$. 


\subsection{Migration of Bacteriological Parameters}

Before the application of the $50 \mathrm{~kg}$ of poultry waste to the soil core, there seem to be less values of Faecal coliform (FC), Total coliform (TC) and Faecal streptococci (FS) at all depths. However, one month after, the bacteriological parameters increased at all depths though the values were higher at depths $0.5 \mathrm{~m}$ to $2.0 \mathrm{~m}$. The trend of increase continued until after five months when it starts decreasing. World Health Organization (WHO) and drinking water quality regulators in Nigeria recommend a value of $0 \mathrm{cfu} / 100 \mathrm{ml}$ as Maximum Contaminant Level (MCL) for bacteriological parameters in water. Application of poultry waste to land has shown to have potential of raising bacteriological presence in water from shallow aquifers in Minna. This may be attributed to the fact that Minna soil has high effective porosity (Alabadan et al., 2009) which allows contaminated water to travel through the soil core without filtering out the bacteriological contents probably due to their very small surface area and presence in high numbers in poultry manure.

As shown in figure 7 , TC has its highest values at depths $0.5 \mathrm{~m}, 1.0 \mathrm{~m}, 1.5 \mathrm{~m}, 2.0 \mathrm{~m}$ and $2.5 \mathrm{~m}$ two months after waste application.

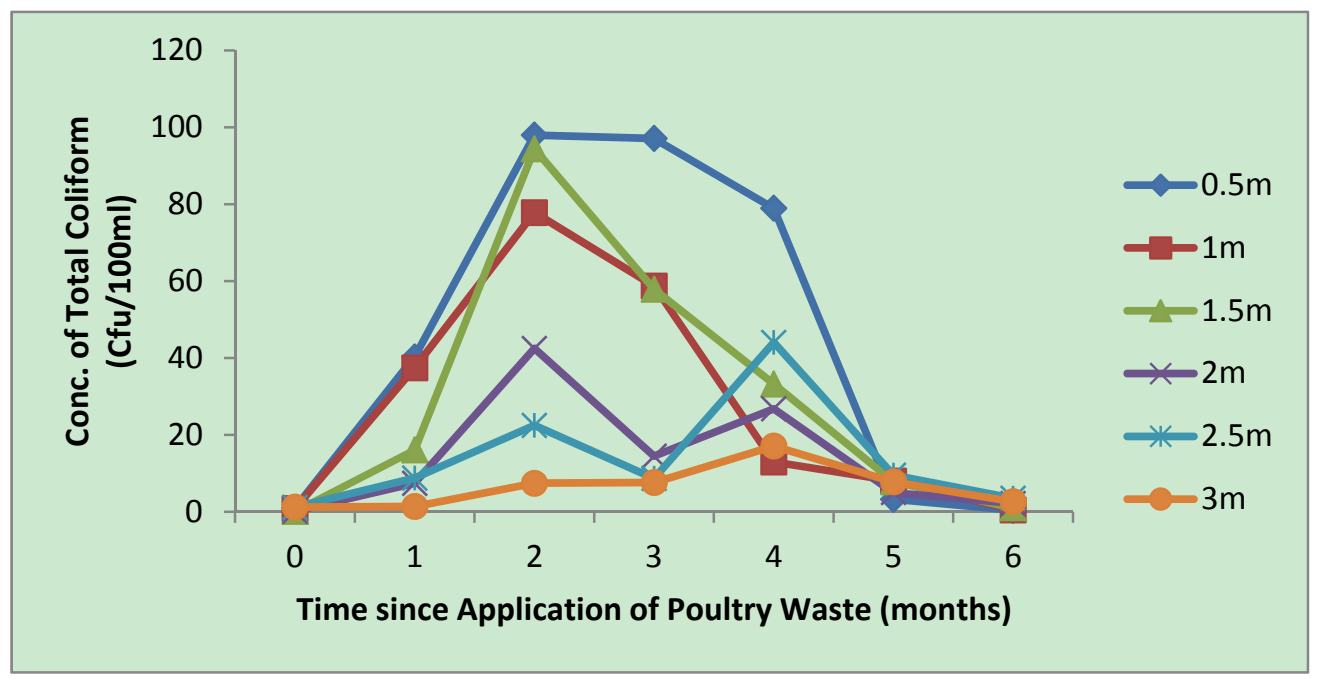

Figure 7. Concentration of total coliform at various depths of the soil core

Therefore, the fast rate at which these bacteriological parameters migrate through Minna soil may make land application and burying as major poultry waste management options unacceptable. Statistical analysis, (Table 3) revealed that depth of water collection introduced a significant effect $(\mathrm{p}<0.05)$ on FC, TC and FS at all depths. Another obvious observation in respect of depth was that the bacteriological values get reduced progressively with increased depth. This may confirm earlier submission by (Isikwue et al., 2011) that increasing the depths of hand dug wells may reduce danger of microbial contamination. However, in locations where water table is very shallow, the well managers have little or no control over depths. Variation also exists in bacteriological values with time as shown in the table.

\subsection{Migration of Heavy Metals within the Soil Core}

Heavy metals migration from dumped poultry waste into the soil core is as presented in table 4 . Though the values of the five heavy metals considered in this research was very low in the water samples collected before poultry waste introduction into the soil, the value increased after one months but did not leach beyond 0.5 meter depth for after three months of application. The heavy metal values reached the highest after one month and starts declining. For the three experimental plots, the values of heavy metals tend to zero value after three months of poultry manure introduction to the soil core, hence their non-inclusion in the result presented in the table. 
Table 4. Average heavy metals contents of the water samples

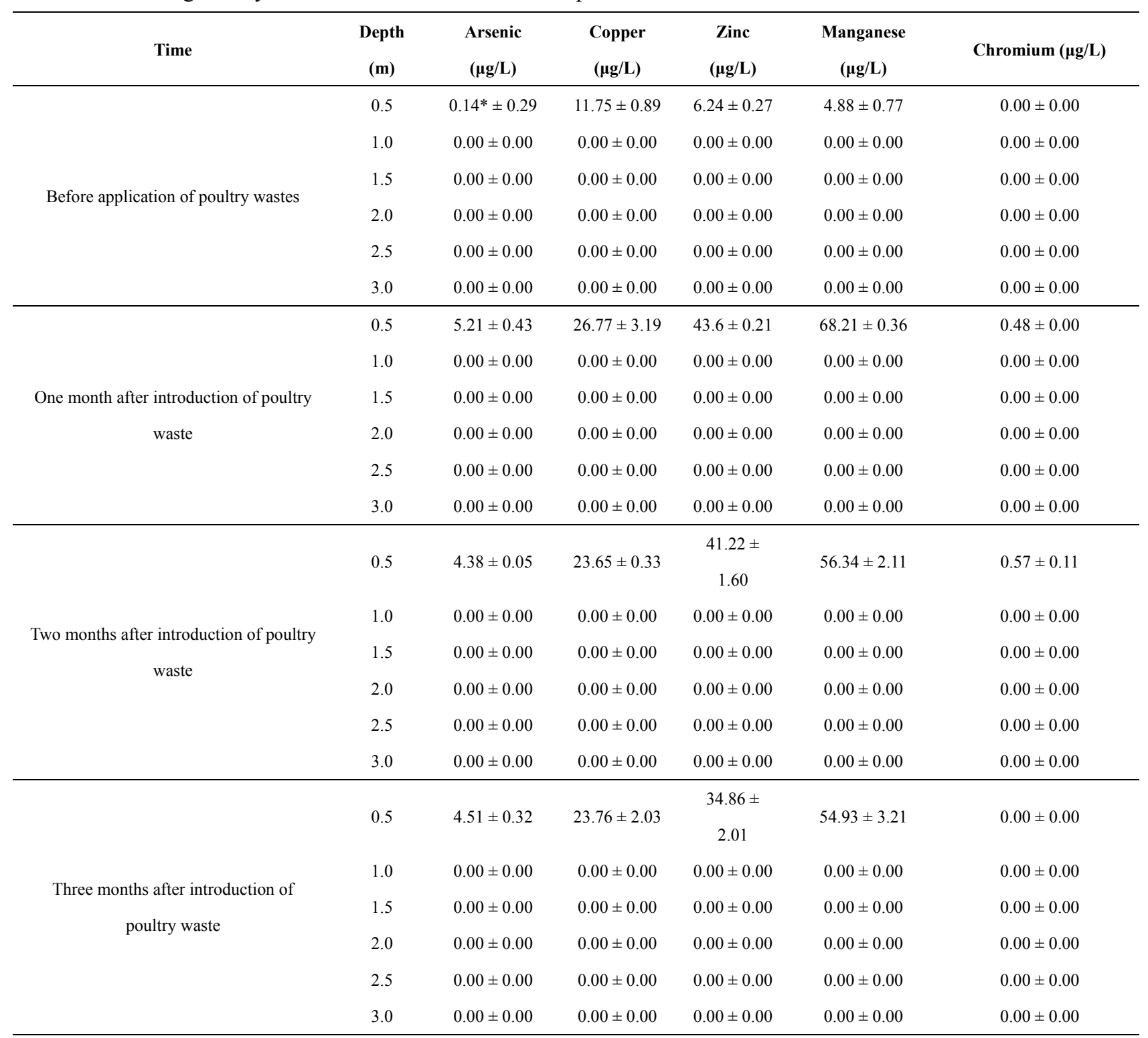

*values are means of triplicate readings \pm standard deviation

This slow movement in the subsoil by heavy metals has been reported by Jackson et al. (2006), therefore, contamination of shallow aquifer of depth $3 \mathrm{~m}$ and above by heavy metals from poultry waste dump may require a continuous dumping of waste on the soil surface for more than six months. This is the case observed in Minna. Analysis has shown that these trace elements are present in the poultry waste and dumping them on soil surface for a long time almost daily or weekly will result in accumulation of the metals in the soil. Though their rate of leaching in the soil has been observed to be slow $(0-0.5 \mathrm{~m}$ in 3 months) they are poorly attenuated in soil (Worall et al., 2002) and have very long half-life (Nickson et al., 2000). Therefore, the shallow aquifers in Minna still stand the risk of heavy metals contamination. The mutagenicity and carcinogenicity of heavy metal have earlier been discussed, the aquifer in Minna need to be protected so that the people living in the area would be protected from these two effects of heavy metals and other serious diseases.

\subsection{Inter-Elemental Correlations}

As shown in Table 5, there are observed relationship between the physico-chemical properties, bacteriological properties of the water samples and some soil properties like depth, and soil $\mathrm{pH}$. The bolden $\mathrm{F}$ values in table 5 indicate significant correlations. From the correlation matrix table, positive correlation was observed between depth of soil and other physico-chemical parameters tested except the soil $\mathrm{pH}$. This relationship may imply that 
the deeper the shallow wells in Minna, the more potable the water becomes because there may likely be a reduction in values of the parameters which in the other word may be termed as contaminants. There is a positive correlation also between soil $\mathrm{pH}$ and all the bacteriological parameters.

Table 5. Spearman's Inter-Elemental Correlation among the water and Wells Parameters

\begin{tabular}{|c|c|c|c|c|c|c|c|c|c|c|c|c|c|c|}
\hline & depth & Soil $p H$ & $E C$ & $T D S$ & $\mathrm{NO}_{3}^{-}$ & $\mathrm{PO}_{4}^{-3}$ & $F C$ & $T C$ & $F S$ & As & $\mathrm{Cu}$ & $Z n$ & $C r$ & $M n$ \\
\hline depth & 1.00 & & & & & & & & & & & & & \\
\hline Soil $p H$ & -0.23 & 1.00 & & & & & & & & & & & & \\
\hline$E C$ & $-0.53 *$ & 0.37 & 1.00 & & & & & & & & & & & \\
\hline$T D S$ & -0.70 & 0.38 & 0.60 & 1.00 & & & & & & & & & & \\
\hline $\mathrm{NO}_{3}^{-}$ & -0.67 & 0.12 & 0.12 & 0.30 & 1.00 & & & & & & & & & \\
\hline $\mathrm{PO}_{4}^{-3}$ & -0.61 & 0.02 & 0.52 & -0.07 & 0.65 & 1.00 & & & & & & & & \\
\hline$F C$ & -0.68 & 0.61 & 0.49 & 0.55 & 0.74 & -0.08 & 1.00 & & & & & & & \\
\hline$T C$ & -0.81 & 0.72 & 0.40 & 0.62 & 0.86 & -0.07 & 0.93 & 1.00 & & & & & & \\
\hline$F S$ & -0.45 & 0.48 & 0.37 & 0.56 & 0.77 & -0.16 & 0.88 & 0.85 & 1.00 & & & & & \\
\hline As & -0.77 & -0.52 & 0.19 & 0.06 & -0.21 & 0.52 & 0.13 & 0.22 & 0.13 & 1.00 & & & & \\
\hline $\mathrm{Cu}$ & -0.75 & -0.61 & 0.43 & 0.41 & 0.30 & -0.14 & 0.36 & 0.21 & 0.31 & 0.70 & 1.00 & & & \\
\hline$Z n$ & -0.63 & -0.82 & 0.15 & 0.39 & 0.09 & -0.12 & 0.41 & 0.34 & 0.38 & 0.60 & 0.79 & 1.00 & & \\
\hline $\mathrm{Cr}$ & -0.53 & -0.95 & -0.27 & -0.04 & 0.20 & 0.79 & -0.18 & -0.19 & -0.14 & -0.78 & 0.86 & 0.49 & 1.00 & \\
\hline$M n$ & -0.63 & -0.84 & -0.04 & -0.04 & 0.04 & 0.83 & -0.01 & -0.08 & -0.07 & -0.68 & 0.42 & 0.56 & 0.80 & 1.00 \\
\hline
\end{tabular}

$* F$ values in bold letters signify significant correlation at $p<0.05$

This may confirm the earlier assertion (Howard et al., 2003) that an alkaline medium favours bacteria growth and guarantee their persistence in soil and water. There exist a negative correlation between heavy metals in the water samples and soil $\mathrm{pH}$ and may point to the fact that acidic medium in soil enhances build-up of heavy metals (Ehler and Goss, 2003).Nitrate and bacteria also exhibit positive relationship which may have showed that their sources are the same and therefore the nitrates detected in the water samples may be categorized as organic nitrogen. High positive correlations that exist between the heavy metals in the table is also an indication that they are all of the same origin.

\section{Conclusion}

This study has showed that the soil on the experimental plots have poor attenuation capacity on poultry manure groundwater contaminants. Nitrates and phosphates were able to leach up to $2.5 \mathrm{~m}$ depth of the undisturbed soil core within 3 months of the experiment though nitrates move faster than other contaminating parameters. The observation which was attributed to high porosity of the soil and high hydraulic conductivity which ranged from $0.489-0.81 \mathrm{~m} /$ day according to hydraulic parameters analysis carried out on the soil of the area. Heavy metals were not able to migrate beyond $0.5 \mathrm{~m}$ depth of the soil core within the experimental period possibly due to slow subsurface movement of heavy metals or high $\mathrm{pH}$ of the soil in the area which does not favour rapid heavy metals movement in the subsurface.

This study proved to be difficult and time consuming in the aspect of digging, rainfall simulation and monthly water sample collection, modeling approach is therefore recommended because it would make the study of contaminants in the subsurface to be easier. The results obtained in this research can be used as baseline and the results of the modeling approach can be extended beyond $3 \mathrm{~m}$ depth covered by this research. The research has also been able to provide contaminants quantity in the poultry waste. This information can be used as input parameters into modern software and models to predict contaminant fate, transport and persistence in Minna shallow aquifer. 


\section{References}

Adeoye, P. A., Hasfalina, C. M., Mohammed, A. S., Thamer, A. M., \& Akinbile, C. O. (2012). Poultry waste effect on shallow groundwater quality in selected farms in Minna, North-central Nigeria. Proceedings of International Conference on Agricultural and Food Engineering for life. University Putra, Malaysia: 554-565.

Adesiji, A. R., \& Jimoh, O. D. (2012). Estimation of runoff from Chanchaga River Basin using Soil-Water Balance Approach. Nig. J. Hyd. Sci., 1, 29-40.

Alabadan, A. B., Adeoye, P. A., \& Folorunso, E. A. (2009). Effect of different poultry wastes on physical, chemical and biological properties of soil. Casp. J. Env. Sci., 7(1), 31-35.

Bergstrom, F. L., \& Kirchmann, H. (1999). Leaching of total nitrogen from nitrogen-15-labeled poultry manure and inorganic nitrogen fertilizer. J. Env. Qual., 28, 1283-1290. https://doi.org/10.2134/jeq1999.00472425002800040032x

Bolan, N. S., Szgozy, A. A., Chuasavathi, T., Seshadri, M. J., Rothrock, J. R., \& Panneerselvam, P. (2010). Uses and management of poultry litter. World. Poultry Sci. J., 66, 673-698. https://doi.org/10.1017/S0043933910000656

Choo, K. H., Lee, H., \& Choi, S. J. (2005). Iron and manganese removal and membrane fouling during UF in conjunction with prechlorination for drinking water treatment. J. Membrane Sci., 267, 18-26. https://doi.org/10.1016/j.memsci.2005.05.021

Chukwu, P., Ejieji, C. Y., \& Alonge, F. S. (2004). Appraisal of prevalence of water-borne and water-based diseases in selected cities of North Central Nigeria. Nig. J. Tech. Dev., 8(2), 209-217.

Collin, M. L., \& Melloul, A. J. (2003). Assessing groundwater vulnerability to pollution to promote sustainable $\begin{array}{llllll}\text { urban and rural development. J. Cleaner Prod., } & \text { 11, }\end{array}$ https://doi.org/10.1016/S0959-6526(02)00131-2

Coufal, C. D., Chavez, C., Niemeyer, P. R., \& Carey, J. B. (2006). Measurement of broiler litter production rates and nutrients content using recycled litter. Poultry Sci. J., 85, 398-403. https://doi.org/10.1093/ps/85.3.398

Edoga, R. N., \& Suzzy, A. B. U. (2008). Effect of temperature changes on evapotranspiration in Minna, Niger State. J.Eng. Appl. Sci., 3(6), 482-486.

Ehler, W., \& Goss, M. J. (2003). Water dynamics in plant Production. CABI Publishing. Wallingford. England. Pp 304. https://doi.org/10.1079/9780851996943.0000

FAO. (1986). Irrigation Water Management. Food and Agricultural Organization (FAO) Training Manual. FAO, Rome. Pp.235.

Gee, C. W., Newman, B. D., Green, S. R., Meissner, R., Rupp, H., Zhang, Z. F., ... Salazar, J. (2009). Passive wick fluxmeters; design considerations and field application. Wat. Res. Research, 45, W04420.

Gehl, R. J., Schmidt, P. J., Stone, L. R., Schlegel, A. J., \& Clark, G. A. (2005). In situ measurements of nitrate leaching implicate poor nitrogen and irrigation management on sandy soils. J. Env. Qua., 34(6), 2243-2254. https://doi.org/10.2134/jeq2005.0047

Goss, M. J., \& Ehlers, W. (2009). The role of lysimeters in the development of our understanding of soil water and nutrient dynamics in ecosystem. Soil Use Man., 25, 213-223. https://doi.org/10.1111/j.1475-2743.2009.00230.x

Goss, M. J., Ehlers, W., \& Unc, A. (2010). The role of lysimeter in the development of our understanding of processes in the vadose zone relevant to contamination of groundwater aquifers. Phy. Chem. Earth, 35, 913-926. https://doi.org/10.1016/j.pce.2010.06.004

Howard, G., Pedley, S., Barrett, M., Nalubega, M., \& Johal, K. (2003). Risk factors contributing to microbiological contamination of shallow groundwater in Kampala, Uganda. Water Res., 37, 3421-3429. https://doi.org/10.1016/S0043-1354(03)00235-5

Isikuwe, M. O., Lorver, D., \& Onoja, S. B. (2011). Effect of depth on microbial pollution of shallow wells in Makurdi metropolis, Benue state, Nigeria. British J. Env. Clim. Change, 1(3), 66-73. https://doi.org/10.9734/BJECC/2011/354

Jackson, B. P., Seaman, J. C., \& Bertsch, P. M. (2006). Fate of arsenic compounds in poultry litter upon land application. Chemosphere, 65, 2028-2034. https://doi.org/10.1016/j.chemosphere.2006.06.065 
Jimoh, O. D., Ayodeji, M. A., \& Mohammed, B. (2003). Effect of agro-chemicals on surface and ground waters in Tunga-Kawo (Nigeria) irrigation scheme. Hyd. Sci. J., 48(6), 1013-1023. https://doi.org/10.1623/hysj.48.6.1013.51426

Karthikeyan, O. P., Murugesan, S., Joseph, K., \& Nagendran, R. (2008). Leaching of inorganic pollutants from fresh and partially degraded municipal solid waste: a lysimeter study under tropical conditions. Int. J. Env. Waste Man., 2(1/2), 49-64. https://doi.org/10.1504/JJEWM.2008.016991

Kulabako, N. R., Nalubega, M., \& Thunvik, R. (2007). Study of the impact of land use and hydrogeological settings on the shallow groundwater quality in a peri-urban area of Kampala, Uganda. The Sci. Total Env., 381, 180-199. https://doi.org/10.1016/j.scitotenv.2007.03.035

Lerner, D. N., \& Harris, B. (2009). The relationship between land use and groundwater resources and quality. Land Use Policy, 26S, S265-S273. https://doi.org/10.1016/j.landusepol.2009.09.005

Nickson, R. T., McArthur, J. M., Ravenscrooft, P., Burgess, W. G., \& Ahmed, K. M. (2000). Mechanism of arsenic release o groundwater, Bangladesh and West Bengal. Appl. Geo. 15, 403-413. https://doi.org/10.1016/s0883-2927(99)00086-4

Nkandawire, T. (2008). Quality of groundwater from shallow wells of selected villages in Blantyre district, Malawi. Phy. Chem. Earth, 33, 807-811. https://doi.org/10.1016/j.pce.2008.06.023

NPC. (2012). Nigeria Population Commission annual reports. Ministry of Internal Affairs, Nigeria. Pp. 57.

Nyenje, P. M., Foppen, J. W., Kulabako, R., Muwanga, A., \& Uhlenbrook, S. (2013). Nutrient pollution in shallow aquifers underlying pit latrines and domestic solid waste dumps in urban slums. J. Env. Man, 122, 15-24. https://doi.org/10.1016/j.jenvman.2013.02.040

Salami, B. F., Oladiran, F. B., \& Jayeola, S. O. (2008). Assessment of shallow groundwater quality around Minna abattoir and central market. Afri. J. Env. Sci. Tech., 11(6), 313-325.

Shekwolo, P. D., \& Brisbe, M. O. (1999). Bacteriological properties of groundwater in parts of Niger State, Nigeria. J. Env. Hyd., 7, 1-9.

Worall, F., Besien, T., \& Kolpin, D. W. (2002). Groundwater vulnerability: interaction of chemical and site properties. The Sci. Total Envi., 299, 131-143. https://doi.org/10.1016/S0048-9697(02)00270-X

\section{Copyrights}

Copyright for this article is retained by the author(s), with first publication rights granted to the journal.

This is an open-access article distributed under the terms and conditions of the Creative Commons Attribution license (http://creativecommons.org/licenses/by/4.0/). 